References and Notes

1. A. Zangwill, Physics at Surfaces (University Press, Cambridge, 1988).

2. S. G. Davison, M. Stęślicka, Basic Theory of Surface States (Oxford Univ. Press, New York, 1992).

3. M. V. Bollinger et al., Phys. Rev. Lett. 87, 196803 (2001).

4. L. Burgi, O. Jeandupeux, A. Hirstein, H. Brune, K. Kern, Phys. Rev. Lett. 81, 5370 (1998).

5. M. F. Crommie, C. P. Lutz, D. M. Eigler, Nature 363, 524 (1993).

6. Y. Hasegawa, P. Avouris, Phys. Rev. Lett. 71, 1071 (1993).

7. J. Repp, G. Meyer, K. H. Rieder, Phys. Rev. Lett. 92, 036803 (2004).

8. M. F. Crommie, C. P. Lutz, D. M. Eigler, Science 262, 218 (1993)

9. N. Nilius, T. M. Wallis, W. Ho, Science 297, 1853 (2002).

10. T. M. Wallis, N. Nilius, W. Ho, Phys. Rev. Lett. 89, 236802 (2002).

11. S. Folsch, P. Hyldgaard, R. Koch, K. H. Ploog, Phys. Rev. Lett. 92, 056803 (2004).

12. J. N. Crain et al., Phys. Rev. B 69, 125401 (2004).

13. J. R. Ahn, H. W. Yeom, H. S. Yoon, I. W. Lyo, Phys. Rev. Lett. 91, 196403 (2003).
14. K. N. Altmann et al., Phys. Rev. B 64, 035406 (2001).

15. R. Losio et al., Phys. Rev. Lett. 86, 4632 (2001).

16. P. Segovia, D. Purdie, M. Hengsberger, Y. Baer, Nature 402, 504 (1999).

17. An STS study of Si(111) $5 \times 2$-Au revealed 1D Schottky barriers between insulating and metallic chain segments.

18. H. S. Yoon, S. J. Park, J. E. Lee, C. N. Whang, I. W. Lyo, Phys. Rev. Lett. 92, 096801 (2004).

19. J. N. Crain et al., Phys. Rev. Lett. 90, 176805 (2003).

20. J. R. Ahn, H. W. Yeom, H. S. Yoon, I. W. Lyo, Phys. Rev. Lett. 91, 196403 (2003).

21. H. W. Yeom et al., Phys. Rev. Lett. 82, 4898 (1999).

22. M. M. J. Bischoff, T. Yamada, A. J. Quinn, H. van Kempen, Surf. Sci. 501, 155 (2002).

23. Two caveats must be considered in interpreting any spatially resolved STS measurements. The DOS is convolved with the finite size of the tip leading to a spatial broadening. Also, a constant-current set point determines the tip-sample separation for each measurement, leading to an exponential increase in the differential conductivity when the tipsample separation decreases, such as off the ends of the chains.

24. Choices with positive $t_{1}$ are ruled out from modeling longer chains.
25. J. N. Crain, D. T. Pierce, data not shown

26. Consistency among different chain lengths requires the inclusion of (i) a nearest-neighbor hopping integral for the end atoms $t_{1 \text { end }}=-0.19 \mathrm{eV}$ that is reduced as compared with the nearest-neighbor hopping integral between central atoms $t_{1}=-0.34 \mathrm{eV}$, (ii) a second-nearest-neighbor hopping integral of $t_{2}=$ $0.10 \mathrm{eV}$, and (iii) binding energies of $\varepsilon_{1}=-0.60 \mathrm{eV}$ for the end atoms, $\varepsilon_{2}=-0.09 \mathrm{eV}$ for the atoms second from the end, and $\varepsilon_{0}=-0.27 \mathrm{eV}$ for the remaining atoms in the interior of the chain. For the four-atom chain there are no middle atoms, so only energies $\varepsilon_{1}$ and $\varepsilon_{2}$ are used.

27. R. F. Peierls, Quantum Theory of Solids (Clarendon, Oxford, 1955).

28. We thank M. D. Stiles for insightful discussions and suggestions concerning modeling, J. A. Stroscio for helpful discussions and for building the STM, R. J. Celotta and J. W. Gadzuk for helpful comments, and S. R. Blankenship for technical assistance. This work was supported in part by the Office of Naval Research.

29 October 2004; accepted 23 December 2004 10.1126/science. 1106911

\title{
Photic Zone Euxinia During the Permian-Triassic Superanoxic Event
}

\author{
Kliti Grice, ${ }^{1 *}$ Changqun Cao, ${ }^{2}$ Gordon D. Love, ${ }^{3}$ \\ Michael E. Böttcher, ${ }^{4}$ Richard J. Twitchett, ${ }^{5}$ \\ Emmanuelle Grosjean, ${ }^{3}$ Roger E. Summons, ${ }^{3}$ \\ Steven C. Turgeon, ${ }^{6}$ William Dunning, ${ }^{1}$ Yugan $\mathrm{Jin}^{2}$
}

\begin{abstract}
Carbon and sulfur isotopic data, together with biomarker and iron speciation analyses of the Hovea-3 core that was drilled in the Perth Basin, Western Australia, indicate that euxinic conditions prevailed in the paleowater column during the Permian-Triassic superanoxic event. Biomarkers diagnostic for anoxygenic photosynthesis by Chlorobiaceae are particularly abundant at the boundary and into the Early Triassic. Similar conditions prevailed in the contemporaneous seas off South China. Our evidence for widespread photiczone euxinic conditions suggests that sulfide toxicity was a driver of the extinction and a factor in the protracted recovery.
\end{abstract}

The most severe extinction of the past 500 million years occurred in the Late Permian $(1,2)$. The biotic crisis was accompanied by an oceanic anoxic event (OAE) that may have lasted up to 8 million years. Although different authors report various anoxic intervals, the most severe conditions persisted during the first 1 to 3 million years $(3,4)$. Anoxia has been proposed to have had a major role in driving the extinction $(5,6)$; surface outcropping of sulfidic waters and emissions of hydrogen sulfide to the atmo-

${ }^{1}$ Curtin University of Technology, Perth, Australia. ${ }^{2}$ Nanjing Institute of Geology and Palaeontology, Nanjing, China. ${ }^{3}$ Massachusetts Institute of Technology, Cambridge, MA 02139, USA. ${ }^{4}$ Max Planck Institute for Marine Microbiology, Bremen, Germany. ${ }^{5}$ Plymouth University, Plymouth, UK. ${ }^{6}$ Oak Ridge National Laboratory, Oak Ridge, TN 37831, USA.

*To whom correspondence should be addressed. E-mail: K.Grice@curtin.edu.au sphere provide a kill mechanism that might account for the terrestrial and marine extinctions (7).

In anoxic zones of modern-day stratified lakes or restricted marine environments (e.g., the Black Sea and Antarctic fjords), conditions are favorable for bacterial reduction of sulfate to sulfide (e.g., 8). Chlorobiaceae (green sulfur bacteria) are typical of these environments in which hydrogen sulfide extends into the photic zone, where it serves as the electron donor required for anoxygenic photosynthesis. Chlorobiaceae use a distinct assemblage of light-harvesting pigments comprising bacteriochlorophylls $c, d$, and $e$ and the carotenoids isorenieratene and chlorobactene. Identification of these compounds, or their diagenetic alteration products, in sediments provides unequivocal evidence for photic zone euxinic (PZE) conditions in the past (e.g., 9-12).
Here, we use carbon and sulfur isotopic data and biomarker and iron speciation analyses in a drill core (Hovea-3) from the onshore Perth Basin, Western Australia (13), to establish the redox conditions in the water column of the southern Tethys Ocean during the Permian-Triassic (P-T) superanoxic event. Biomarkers diagnostic for anoxygenic photosynthesis by Chlorobiaceae were identified in P-T boundary sediments of the organic-matter (OM)-rich Hovea-3 core and in coeval samples from the OMlean Meishan-1, a new core drilled at the type section of Meishan, South China (fig. S1); these biomarkers demonstrate that waters of the Tethys Ocean were periodically euxinic in the photic zone during and after the extinction event.

Changhsingian and Griesbachian sediment samples of Hovea-3 (1960- to 1995-m depth) contain $\mathrm{C}_{18}$ and $\mathrm{C}_{19}$ aryl isoprenoids (Figs. $1 \mathrm{~A}$ and $2 \mathrm{~A}$ ), and the Griesbachian sediments contain isorenieratane, the $\mathrm{C}_{40}$ parent hydrocarbon (Figs. $1 \mathrm{~A}$ and $2 \mathrm{~B}$ and fig. S2). Highly specific bacteriochlorophylls can also give rise to distinctive maleimides (9). Methyl iso-butyl maleimide was identified in the polar fractions [see (13) for separation of maleimides]. The highest concentrations of all these pigment derivatives are preserved in the Griesbachian, reflecting high green sulfur bacterial activity and, thus, PZE conditions. Isorenieratane and aryl isoprenoids (including low pristane/phytane ratios) also occur in the latest Changhsingian and earliest Induan (Griesbachian) sediments (beds 22 to 27) of the global boundary stratotype section and point (GSSP) at Meishan, South China, which suggests that PZE conditions were widespread (Fig. 1B and Fig. 3).

Although the above data provide evidence for PZE during the P-T transition, the presence of benthic epifaunal macroinvertebrates such as Claraia and spirorbids dem- 
onstrates that, because these animals would have required some oxygen, the euxinia was episodic (14).

Independent evidence for euxinic conditions in the Lower Triassic seas off Australia is provided by high amounts of metalloporphyrins, in particular vanadyl (VO) porphyrins (Fig. 2C) (15). These samples also contained high concentrations of $\mathrm{Ni}$ (II) porphyrins.

We also measured iron species, dithioniteextractable $\left(\mathrm{Fe}_{\mathrm{D}}\right)$, pyrite $\left(\mathrm{Fe}_{\mathrm{P}}\right)$, and total iron $\left(\mathrm{Fe}_{\mathrm{T}}\right)(16)$ in the Hovea- 3 sediments. $\left(\mathrm{Fe}_{\mathrm{D}}+\right.$ $\left.\mathrm{Fe}_{\mathrm{P}}\right) / \mathrm{Fe}_{\mathrm{T}}$ values up to 0.7 indicate euxinic conditions in the basal-most Triassic (Fig. 2D), comparable to values reported from the modern euxinic Black Sea (17). Variations in the ratio may be due to changes in the oxycline position, the area of sediment covered by anoxic waters, and changes in weathering rates.

The isotopic composition of the oceanic sulfur reservoir is partly controlled by the balance of bacterial sulfate reduction and sulfide oxidation. These processes lead to ${ }^{34} \mathrm{~S}$-depleted sulfide and related pyrite (18) and may result in sulfate relatively enriched in ${ }^{34} \mathrm{~S}$. Burial of pyrite thus removes isotopically light sulfur from the seawater pool. Sedimentary sulfides in the Hovea-3 samples (Fig. 2E) are depleted in ${ }^{34} \mathrm{~S}$ compared with contemporaneous seawater sulfate $(19,20)$ and follow a trend toward heavier values approaching the P-T transition, as seen in carbonateassociated sulfate in other P-T samples from northern Italy and Iran $(19,20)$.

Sulfur-isotope fractionations between sedimentary pyrite and contemporary sulfate $(19,20)$ up to about 50 to 60 per mil (\%o) indicate that reservoir effects did not substantially influence the isotopic signatures. The ${ }^{34} \mathrm{~S} /{ }^{32} \mathrm{~S}$ ratios for the sulfides in the Basal Triassic of the Perth Basin are consistent with euxinic conditions as found in the modern Black Sea and the Pliocene Mediterranean Basin (21). The change in isotope discrimination implies that there was a perturbation in the sulfur cycle in the Upper Permian and a relative increase in the fraction of sulfur buried as pyrite in the Lower Triassic compared with the Permian (22) or that there was a change in other factors (e.g., quality of $\mathrm{OM}$ ) influencing overall sulfur isotope discrimination. Isotope shifts in reduced sulfur across the P-T boundary indicate changes in the sulfur cycle similar to those reported in sections from Japan (22).

Stable carbon isotopic data from the bulk kerogen fraction of Hovea-3 record an abrupt $7.5 \%$ negative shift from the Upper Permian to the Lower Triassic consistent with a localized palynofacies change from charcoalwood dominated $\mathrm{OM}$ to algal-amorphous $\mathrm{OM}$, respectively (23). In contrast, $\delta^{13} \mathrm{C}$ values of the molecular fossils pristane and phytane vary gradually across the P-T transition (Fig. 2F), representing in part a change in $\mathrm{OM}$ inputs or an increase in stratification toward the Triassic that caused enhanced recycling of ${ }^{13} \mathrm{C}$-depleted $\mathrm{CO}_{2}$. However, recent $\delta^{13} \mathrm{C}$ data on higher plant and phytoplankton biomarkers show similar isotopic changes across the P-T transition, which indicates a global disruption of the carbon cycle (24).

The $\delta^{13} \mathrm{C}$ values of pristane and phytane, derived from phytol side chains of the chlorophylls of algae and cyanobacteria, are robust proxies for the isotopic composition of phytoplankton (e.g., 25, 26). In contrast,
$\mathrm{C}_{14}-\mathrm{C}_{18} n$-alkyl carbon chains have many inputs, comprising primary producers and heterotrophs, and their $\delta^{13} \mathrm{C}$ values represent a weighted average of these. If derived from primary sources such as algae and cyanobacteria, they should be depleted in ${ }^{13} \mathrm{C}$ compared with the co-occurring isoprenoids by $1.5 \%$ o (e.g., 25, 26). This pattern is observed in the Triassic data (Fig. 4), in which there is independent evidence, such as the abundance of porphyrins and algal microfossils, for high primary productivity. Alternatively, isotopic enrichment of $\mathrm{C}_{14}-\mathrm{C}_{18} n$-alkyl carbon chains can occur through heterotrophic processing of primary photosynthate or dom-

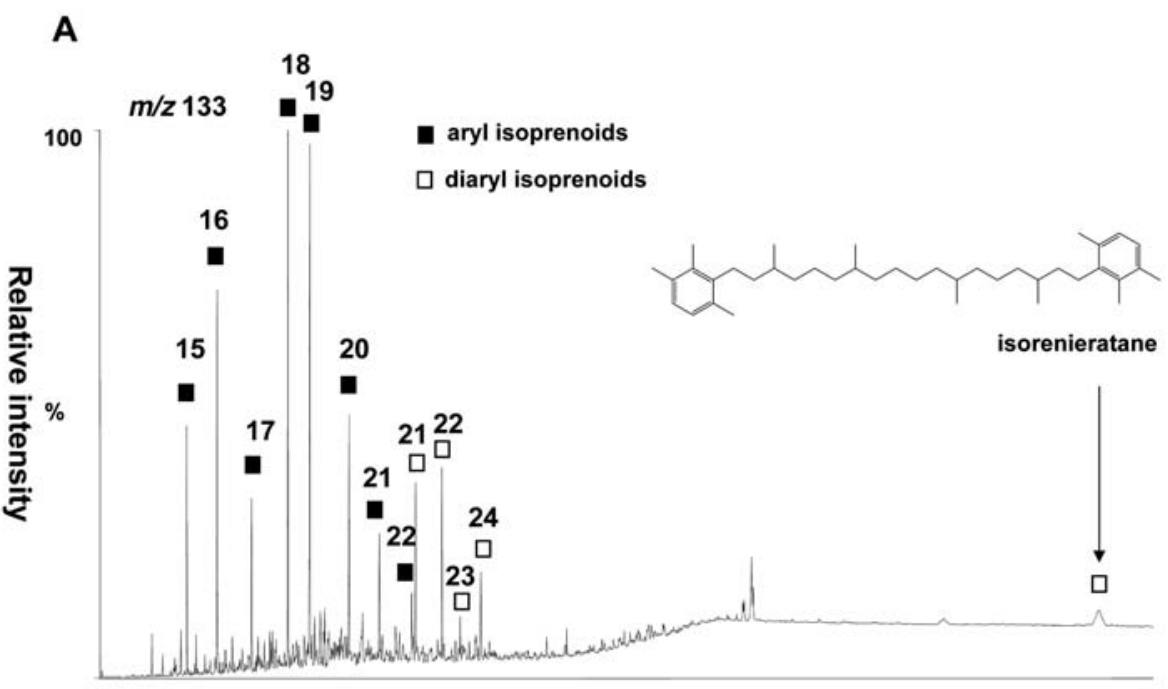

Relative retention time

B

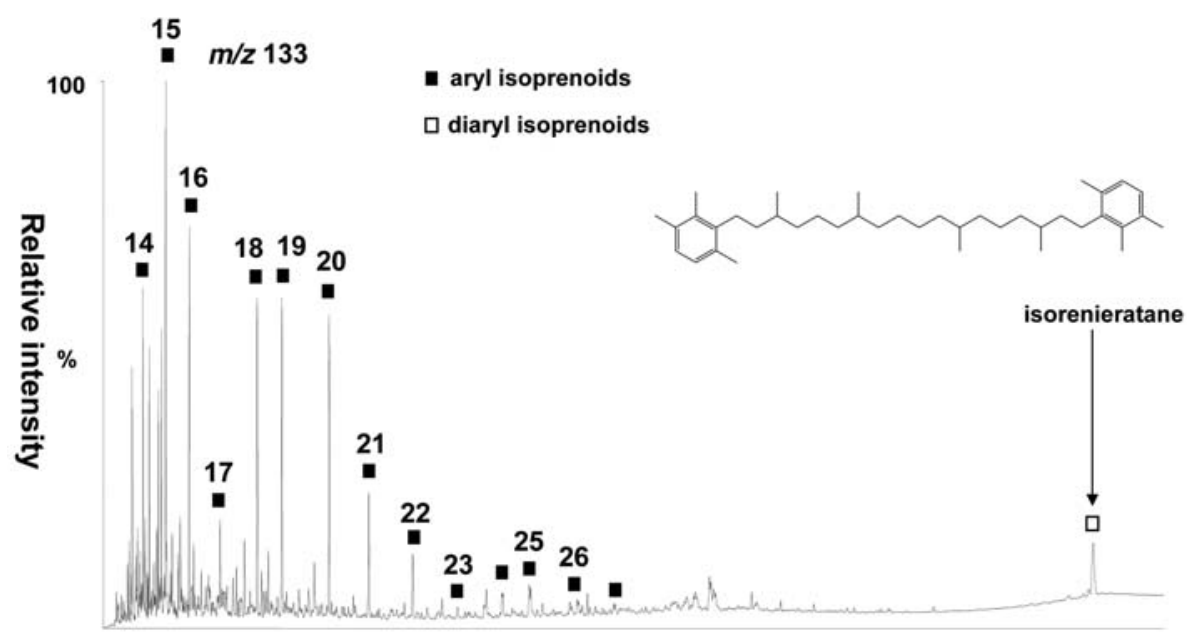

\section{Relative retention time}

Fig. 1. Typical gas chromatography-mass spectrometry selected-ion chromatogram for the 133-Da fragment ion that is diagnostic for aryl isoprenoids of an aromatic hydrocarbon fraction [see (14) for fractionation of extracts]. (A) From $1979.9 \mathrm{~m}$ (Hovea-3). This trace shows pseudohomologous series $\mathrm{C}_{12^{-}}$ $\mathrm{C}_{31}$ compounds identified as aryl isoprenoids with a 2,3,6-trimethyl substitution pattern and the $\mathrm{C}_{40}$ biomarker isorenieratane. These hydrocarbons were identified by comparison with a reference sample (fig. S2). (B) From $107.94 \mathrm{~m}$ (Meishan-1). This trace for Meishan Bed 24-6 shows an assemblage of Chlorobiaceae biomarkers similar to those seen in Hovea-3. The enhanced relative abundance of isorenieratane reflects a lower degree of thermal maturity in the sediments from South China. 


\section{REPOR T S}

Fig. 2. Composite plot of Hovea-3 organic and inorganic data. (A) Aryl isoprenoid concentrations ( $\mu \mathrm{g} / \mathrm{g}$ of total organic carbon). (B) Isorenieratane concentrations $(\mu \mathrm{g} / \mathrm{g}$ of total organic carbon). (C) Concentrations of vanadyl and nickel porphyrins ( $\mu \mathrm{g} / \mathrm{g}$ of total organic carbon) [see (14) for analysis of porphyrins]. (D) $\mathrm{Fe}_{\mathrm{HR}} / \mathrm{Fe}_{\mathrm{T}}$ ratios. $\mathrm{Fe}_{\mathrm{HR}}$, highly reactive iron; $\mathrm{Fe}_{\mathrm{T}}$, total iron; $\mathrm{Fe}_{\mathrm{p}}$, pyritic iron [see (14) for isolation of iron species]. (E) $\delta^{34} S$ of pyrite relative to Vienna Canyon Diablo troilite (VCDT) standard in \%o [see (14) for sulfur isotope analyses]. (F) $\delta^{13} \mathrm{C}$ of pristane and phytane relative to Vienna Pee Dee belemnite (VPDB) standard in \%o [see (14) for 5A molecular sieving and compound-specific isotope analyses].

Fig. 3. Composite plot of Meishan-1 organic geochemical, biomarker, and bulk carbon isotopic data. Pristane/ phytane ratios show their lowest values just below and just above the extreme negative carbon-isotopic excursion. Maxima of aryl isoprenoid and isorenieratane abundances in beds 24 to 27 bracket the extinction horizon. Notably, there are additional maxima of these markers at beds 34,35 , and 37 . which indicates that there was a waxing and waning of PZE conditions that continued well into the Triassic (fig. S1).

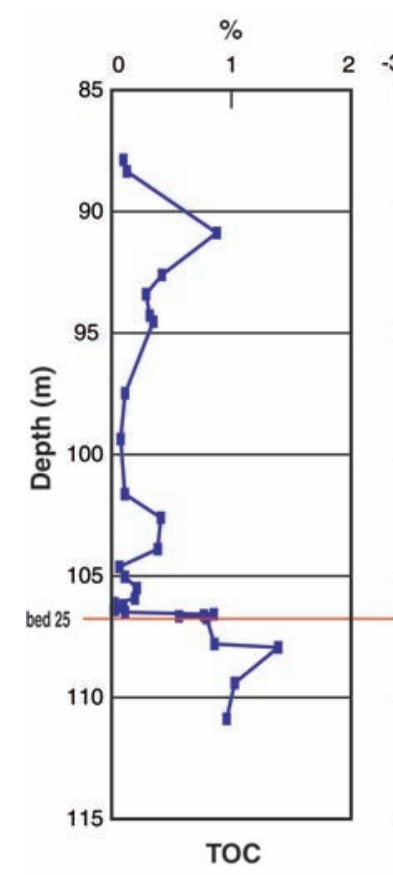

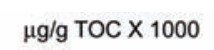

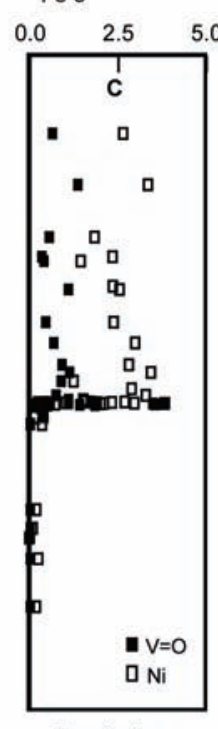

Porphyrins

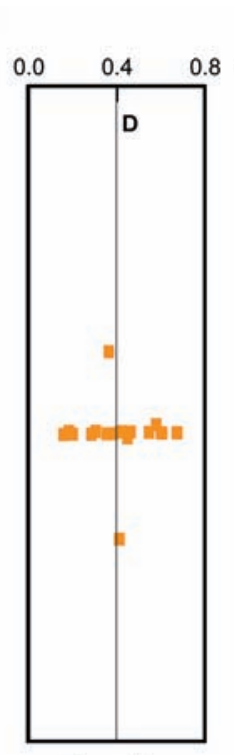

FeHR/Fet

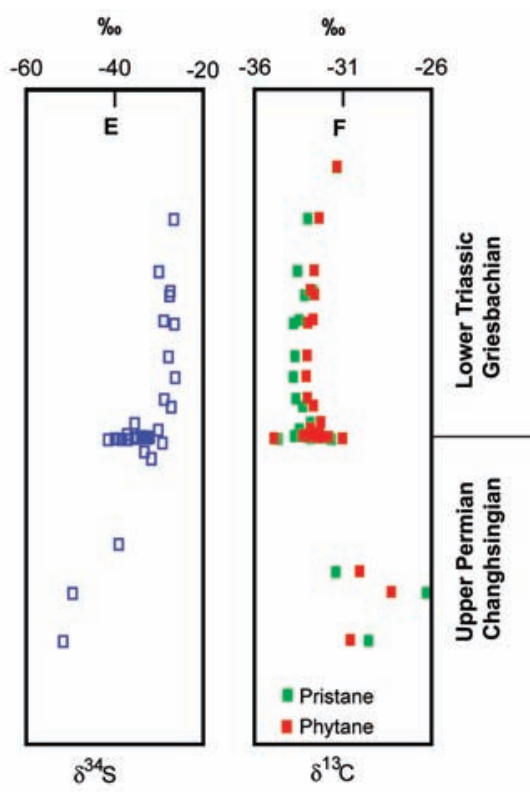

inant inputs of isotopically heavy bacterial biomass. This pattern of anomalous isotopic ordering is seen in the Permian sediments. Figure 4 demonstrates this phenomenon, which suggests that there was a shift in the mode of carbon cycling at the P-T transition in Hovea-3. A similar reversal in the expected $\mathrm{C}$-isotopic relation between polymethylenic and polyisoprenoid lipids has been reported for the Proterozoic-Cambrian transition (27). Moreover, this transition in Cisotopic relations is also evident in data from the P-T transition of Western Slovenia (28), where the isotopic trends of inorganic carbon and kerogen are similar to those seen at Meishan and the Southern Alps. Together, these data provide further evidence for a switch in the mode or extent of organic carbon remineralization at the P-T transition.

The data show that PZE conditions occurred during the P-T superanoxic event and document a major disruption of the carbon and sulfur cycles. The onset of PZE in Hovea-3 coincides with a sharp facies change, reflecting rapid transgression (e.g., 23). The association of oxygen-poor water and rapid transgression is key for the hypothesis that anoxia caused the extinction event (5). Given

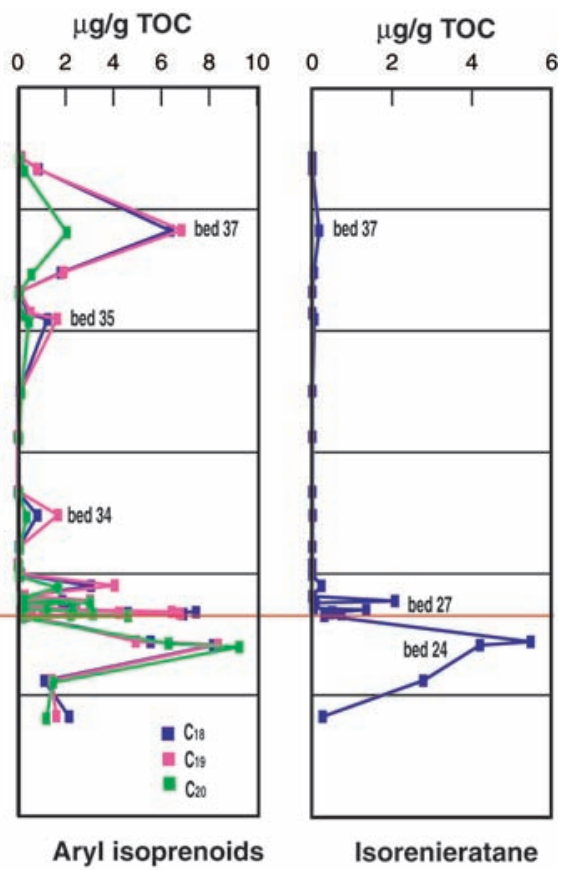

that similar conditions prevailed elsewhere in the Tethys Ocean during the P-T event, we propose that sulfide toxicity in the ocean and emissions of hydrogen sulfide to the atmosphere were important drivers of the largest mass extinction in the past 500 million years and may have also been a factor in the protracted recovery (7).

The local association of PZE and highsedimentary total organic carbon contents (TOC) at Hovea- 3 are similar to those of other Mesozoic OAEs (29). However, the conditions creating the record here were not repeated elsewhere, even within Western 
Fig. 4. $\Delta \delta=$ (average $\delta^{13} \mathrm{C}$ of $n-\mathrm{C}_{17}$ and $\left.n-C_{18}\right)$ - (average $\delta^{13} C$ of pristane and phytane) \%o (relative to VPDB standard in \%o) with depth (meters). Measurements determined by isotoperatio-monitoring gas chromatographymass spectrometry (IsoPrime, Micromass, Manchester, UK) of saturate, branched/ cyclic, and $n$-alkane fractions [see (14) for $5 \mathrm{~A}$ molecular sieving and compoundspecific isotope analyses].

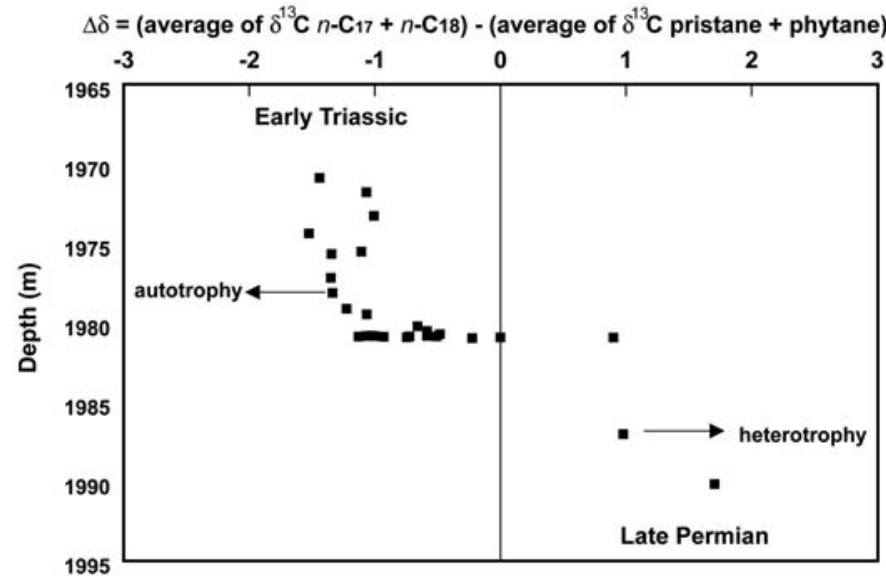

Australia, and must have been very localized. Because PZE also occurred in the contemporaneous seas off South China, localized high algal productivity probably played a key role in the formation of a petroleum-rich source rock in the Perth Basin.

References and Notes

1. D. Erwin, Nature 367, 231 (1994)

2. M. J. Benton, R. J. Twitchett, Trends Ecol. Evol. 18, 358 (2003)

3. P. B. Wignall, R. J. Twitchett, Science 272, 1155 (1996).

4. Y. Isozaki, Science 276, 235 (1997).

5. P. B. Wignall, A. Hallam, Palaeogeogr. Palaeoclimatol. Palaeoecol. 93, 21 (1992)

6. A. H. Knoll, R. K. Bambach, D. E. Canfield, J. P. Grotzinger, Science 273, 452 (1996).

7. L. R. Kump, A. Pavlov, M. Arthur, Y. Kato, A. Riccardi, Abstracts of GSA Annual Meeting, Paper 81-6 (Geological Society of America, Seattle, WA, 2-5 November 2003)

8. T. Trull et al., EOS Trans. Am. Geophys. Union $\mathbf{8 2}$, 306 (2001).
9. K. Grice et al., Geochim. Cosmochim. Acta 60, 3913 (1996).

10. R. E. Summons, T. G. Powell, Geochim. Cosmochim. Acta 51, 557 (1987).

11. M. Koopmans et al., Geochim. Cosmochim. Acta 60 4467 (1996)

12. K. Grice, P. Schaeffer, L. Schwark, J. R. Maxwell, Org. Geochem. 25, 131 (1996).

13. Materials and methods are available as supporting material on Science Online.

14. B. M. Thomas et al., Aust. J. Earth Sci. 51, 423 (2004).

15. Sedimentary porphyrins provide a link to precurso chlorophylls in photosynthetic organisms indicative of primary production in paleowaters. Ni/VO porphyrin ratios are indicators of redox conditions (30).

16. $\mathrm{Fe}_{\mathrm{HR}}=\mathrm{Fe}_{\mathrm{D}}+\mathrm{Fe}_{\mathrm{p}}$ to $\mathrm{Fe}_{\mathrm{T}}$ is an indicator of watercolumn redox conditions in ancient/modern environments $(17,31) . \mathrm{Fe}_{\mathrm{HR}} / \mathrm{Fe}_{\mathrm{T}}>0.4$ are typical for euxinic settings with pyrite formation in the water column. $\mathrm{Fe}_{\mathrm{HR}} / \mathrm{Fe}_{\mathrm{T}}$ values $<0.4$ are found in sediments below oxic bottom waters, where pyrite precipitates in the sediment. $\mathrm{Fe}_{\mathrm{HR}} / \mathrm{Fe}_{\mathrm{T}}$ ratios $<0.4$ do not exclude deposition in a euxinic environment but may indicate changes in the source/depositional setting (17).

17. T. F. Anderson, R. Raiswell, Am. J. Sci. 304, 203 (2004).
18. D. E. Canfield, A. Teske, Nature 382, 127 (1996).

19. R. J. Newton, E. L. Pevitt, P. B. Wignall, S. H. Bottrell, Earth Planet. Sci. Lett. 218, 331 (2004).

20. C. Korte et al., Int. J. Earth Sci. 93, 565 (2004).

21. H. F. Passier et al., Nature 397, 146 (1999).

22. Y. Kajiwara, S. Yamakita, K. Ishida, H. Ishiga, A. Imia, Palaeogeogr. Palaeoclimatol. Palaeoecol. 111, 367 (1994).

23. C. B. Foster, G. A. Logan, R. E. Summons, J. D. Gorter, D. S. Edwards, Aust. Pet. Prod. Explor. Assoc. J. 37 472 (1997)

24. K. Grice et al., unpublished data.

25. J. M. Hayes, Rev. Mineral. Geochem. 43, 225 (2001).

26. S. Schouten et al., Geochim. Cosmochim. Acta 62, 1397 (1998).

27. G. A. Logan, J. M. Hayes, G. B. Hieshima, R. E. Summons, Nature 376, 53 (1995).

28. V. Schwab, J. E. Spangenburg, Appl. Geochem. 19, 55 (2004).

29. R. D. Pancost et al., J. Geol. Soc. London 161, 353 (2004).

30. M. D. Lewan, J. B. Maynard, Geochim. Cosmochim. Acta 46, 2547 (1982)

31. Y. Shen, A. H. Knoll, M. R. Walter, Nature 423, 632 (2003).

32. We thank Origin Energy for collecting a unique, corebased maturity profile of the Hovea core of the Perth Basin. We also thank S. Wang, G. Chidlow, and Geoscience Australia (Canberra) for technical input and M. Kuypers, D. Fike, and two anonymous reviewers for comments. K.G. acknowledges the Australian Research Council for funding. C.Q.C. and Y.G.J. were supported by the China Ministry of Science and Technology and the National Natural Science Foundation of China. M.E.B. acknowledges Max-Planck-Gesellschaft for support. Work at the Massachusetts Institute of Technology was supported by NASA Exobiology grant NAG5-1236.

Supporting Online Material

www.sciencemag.org/cgi/content/full/1104323/DC1

Materials and Methods

Figs. S1 and S2

References

20 August 2004; accepted 6 January 2005

Published online 20 January 2005;

$10.1126 /$ science. 1104323

Include this information when citing this paper.

\title{
Abrupt and Gradual Extinction Among Late Permian Land Vertebrates in the Karoo Basin, South Africa
}

\section{Peter D. Ward, ${ }^{1}$ * Jennifer Botha, ${ }^{3}$ Roger Buick, ${ }^{2}$ Michiel O. De Kock, ${ }^{5}$ Douglas H. Erwin, ${ }^{6}$ Geoffrey H. Garrison, ${ }^{2}$ Joseph L. Kirschvink, ${ }^{4}$ Roger Smith $^{3}$}

\begin{abstract}
The Karoo basin of South Africa exposes a succession of Upper Permian to Lower Triassic terrestrial strata containing abundant terrestrial vertebrate fossils. Paleomagnetic/magnetostratigraphic and carbon-isotope data allow sections to be correlated across the basin. With this stratigraphy, the vertebrate fossil data show a gradual extinction in the Upper Permian punctuated by an enhanced extinction pulse at the Permian-Triassic boundary interval, particularly among the dicynodont therapsids, coinciding with negative carbon-isotope anomalies.
\end{abstract}

The Permian extinction is universally portrayed as the most catastrophic of all Phanerozoic mass extinctions (1), yet its cause remains problematic. Various hypothe- ses include climate change due to increased atmospheric $\mathrm{CO}_{2}$ and/or $\mathrm{CH}_{4}$ (2), the effects of extraterrestrial impact (3-5), the effects of the eruption of the Siberian Traps, and some synergistic combination of these (6), among others. An important test of any mechanism is a consideration of the pattern of extinctions. The marine extinctions are well described in several areas, notably Meishan, China (7). Here, we report new chemostratigraphic, biostratigraphic, and magnetostratigraphic data from multiple stratigraphic sections located in the Karoo basin of South Africa that provide an exceptionally detailed record of the terrestrial extinctions.

Permian-Triassic (P-T) strata in the central Karoo basin provide the most intensively investigated record of vertebrate fossils from

${ }^{1}$ Department of Biology, ${ }^{2}$ Department of Earth and Space Sciences, University of Washington, Seattle, WA 98195, USA. ${ }^{3}$ Karoo Paleontology, Iziko: South African Museum, Cape Town, South Africa. ${ }^{4}$ Division of Geological and Planetary Sciences, California Institute of Technology, Pasadena, CA 91125, USA. ${ }^{5}$ Department of Geology, Rand Afrikaans University, Johannesburg, South Africa. ${ }^{6}$ Department of Paleobiology, MRC-121 Smithsonian Institution, Washington, DC 20013, USA

*To whom correspondence should be addressed. E-mail: argo@u.washington.edu 


\section{Science}

\section{Photic Zone Euxinia During the Permian-Triassic Superanoxic Event}

Kliti Grice, Changqun Cao, Gordon D. Love, Michael E. Böttcher, Richard J. Twitchett, Emmanuelle Grosjean, Roger E. Summons, Steven C. Turgeon, William Dunning and Yugan Jin

Science 307 (5710), 706-709

DOI: 10.1126/science.1104323originally published online January 20, 2005

ARTICLE TOOLS

SUPPLEMENTARY

MATERIALS

REFERENCES

PERMISSIONS http://science.sciencemag.org/content/307/5710/706

http://science.sciencemag.org/content/suppl/2005/03/11/1104323.DC1

This article cites 26 articles, 6 of which you can access for free http://science.sciencemag.org/content/307/5710/706\#BIBL

http://www.sciencemag.org/help/reprints-and-permissions 